\title{
Attack Behavior of Elasmus polistis Burks (Hymenoptera: Eulophidae) in Nest of Polistes versicolor (Oliver) (Hymenoptera: Vespidae) and its Defensive Behavior
}

\author{
Thiago Marinho Alvarenga ${ }^{\circledR}$, Yuri Fanchini Messas ${ }^{1}$, Hebert da Silva Souza1, \\ Luana Leite Guimarães Santos ${ }^{2}$ \& Jober Fernando Sobczak ${ }^{3}$
}

1. Universidade Estadual de Campinas, e-mail: marinho.bio@gmail.com (Autor para correspondência ${ }^{\bowtie}$ ), yurimessas@gmail.com, hssouza.bio@gmail.com. 2. Instituto Federal de Ciência e Tecnologia do Triângulo Mineiro, e-mail: luana.santos628@gmail.com. 3. Universidade da Integração Internacional da Lusofonia Afro-brasileira, e-mail: jobczak@gmail.com.

\section{EntomoBrasilis 8 (2): 155-158 (2015)}

Abstract. The attack behavior of Elaumus polistis Burks in the nest cells of Polistes versicolor (Oliver) was recorded for the first time in South America. We observed that $E$. polistis flies in front of the $P$. versicolor nest, enters inside it and oviposits on wasps prepupae and pupae, possibly through the cells that compose the nest. Despite the obvious defensive behavior of the wasps described here, we found that $E$. polistis is efficient in parasitizing the pupae.

Keywords: Ectoparasitoid; Eulophinae; Circular formation; Host; Neotropical.

\section{Comportamento de Ataque de Elasmus polistis Burks (Hymenoptera: Eulophidae) a Ninho de Polistes versicolor (Oliver) (Hymenoptera: Vespidae) e seu Comportamento de Defesa}

Resumo. O comportamento de ataque de Elasmus polistis Burks em células do ninho de Polistes versicolor (Oliver) foi registrado pela primeira vez na América do Sul. Observou-se que E. polistis voa em frente ao ninho de P. versicolor, ingressa em seu interior e oviposita sobre as pré-pupas e pupas das vespas, possivelmente através das células que compõem o ninho. Apesar do evidente comportamento de defesa das vespas aqui descrito verificouse que $E$. polistis é eficiente em parasitar suas pupas.

Palavras-chave: Ectoparasitoide; Eulophinae; Formação circular; Hospedeiro; Neotropical.

p arasitoid wasps can cause high mortality in their population hosts. Thus, any characteristic that helps to reduce the chances that the individual is parasitized tends to be favored by natural selection (HANSON \& GAULD 2006).

Arms races are generally viewed as attack-defense "games" which occur over long periods of time, gradually shaping species interactions (Futuyma \& Slatkin 1983; DietL \& Kelley 2002). Thus, the coevolutionary analyzes are increasing their importance to ecological, epidemiological and conservation biology studies, since they began to realize how quickly the results of interactions between species can change (THOMPSON 2001).

According Jolivet et al. (1990), circular defense strategy (cycloalexy) is found irregularly in the animal kingdom, and attains perfection in some leaf-beetles and sawflies. It is intimately linked to aggressive displays (biting, regurgitation, reflex-bleeding). However Dury et al. (2014) conducted a review in which they proposed three criteria needed to define this behavior: (1) individuals form a circle; (2) defensive attributes of the individuals are positioned on the periphery of the circle, and as a result, the periphery of the circle uniformly contains either heads or abdomens and, (3) animals preemptively adopt the circle as a resting formation, meaning it is not necessary to observe predation.

Elasmus is the only genus of the Elasmini (Hymenoptera: Eulophidae), which includes 248 described species and has a cosmopolitan distribution (Noyes 2014). The larvae of most
Elasmus species are gregarious and primary ectoparasitoids of Hispinae (Coleoptera: Chrysomelidae) (Сооте 1997) and Lepidoptera larvae or prepupae, but some species are secondary parasitoids of Braconidae and Ichneumonidae prepupae (GIBSON 1993) and others are primary ectoparasitoids of Vespidae (Polistes) (COOTE 1997; DORFEY \& KOHLER 2011).

The species Elasmus polistis Burks (Figure 1) is known as a gregarious parasitoid of Polistes prepupae or pupae (NELSON 1976), whereas most of the registrations have occurred in North America (REED \& Vinson 1979; MACOM \& LANDOLT 1995) and only one in Brazil (Rio Grande do Sul state) (DORFEY \& KÖHLER 2011). Despite reports of hosts used by the wasps of the genus Elasmus, there are no detailed descriptions of Polistes versicolor (Oliver) defensive behavior facing the attacks of $E$. polistis. In this study we describe the behaviors that mediate this interaction in four nests of $P$. versicolor.

The observations were carried out between 3:00 and 6:00 p.m. on March 6, 2013 and February 2 to 10, 2015 on the premises of the Base Ecológica da Serra do Japi $\left(23^{\circ} 15^{\prime} \mathrm{S}, 46^{\circ} 57^{\prime} \mathrm{W}\right)$, located in Jundiaí, São Paulo, Brazil, at an elevation of $1000 \mathrm{~m}$. The description of the attack behavior of $E$. polistis and defense by $P$. versicolor were made from the analysis of photographs and

Financial support: Instituto Nacional de Ciência e Tecnologia dos Hymenoptera Parasitoides da Região Sudeste Brasileira (HYMPAR/Sudeste - CNPq/FAPESP/CAPES); Conselho Nacional de Desenvolvimento Cientifico e tecnológico (CNPq) . 
videos captured using a Canon EOS 5D Mark II digital camera with a Canon EF 100mm f/2.8 macro lens. The host wasp nest was collected, and enclosed in a plastic recipient $(13 \times 11 \times 10 \mathrm{~cm})$ maintained in the laboratory to obtain the adult $P$. versicolor and $E$. polistis wasps. After emergence, the specimens were enclosed in a plastic recipient containing 70\% ETOH and deposited in the Insetos Entomófagos Oscar Monte (IB-CBE) collection, of the Instituto Biológico, at Campinas, São Paulo State, Brazil (Costa, V.A., curator).

The attack behavior starts with $E$. polistis wasp flying around the nest of $P$. versicolor (SANTOS et al. 2013, see 0-14 seconds in the video image; Figure 2). After a few seconds, E. polistis approaches the nest cells of $P$. versicolor, passing among the $P$. versicolor wasps who take care of the nest, until reaching the pupae. The attack may occur on the upper (see Figure 2a), middle (Figure $2 b$ ) or lower (Figure 2c) portion of the nest. The parasitoid attacks pupae and prepupae, which are located within cells already closed. Thus, the parasitoid wasp reaches the closed cells through adjacent open cells. It was not possible to observe how the oviposition occurs, but it is probably realized by puncturing the wall of the nest with the ovipositor. Subsequently, the parasitoid leaves the nest and lands in regions close to it (Figure 2d). This sequence of behaviors occurred successive times for each $E$. polistis individual with 4-6 assaults per minute.

In all recorded attacks whenever the wasps perceived the presence of the parasitoid, they displayed aggressive behavior characterized by intense vertical open and close wing agitation movements, additionally using its mandibles to attack the parasitoids. This defensive behavior can dispel and avoid parasitoid attack, in addition to increasing the surface patrolling of the nest, probably decreasing the frequency of parasitized pupae. LuTz et al. (1984) also registered the defense behavior of Polistes exclamans Viereck and Polistes instabilis Saussure against E. polistis in
North America.

At certain times during the E. polistis attack, the wasps showed a circular formation around the nest with a wasp at the center verifying the open cells, much like the cycloalexy behavior proposed by Jolivet et al. (1990) (see Figure 3). However according to DuRY et al. (2014) in spite of this circular formation, this behavior is not characterized as cycloalexy because that formation is undertaken only when defending the nest.

The presence of defensive behaviors presented by $P$. versicolor appears not to successfully prevent the occurrence and highfrequency of $E$. polistis attacks, since the attack is made perpendicular to the edges of the nest, avoiding the area of patrolling wasps. Thus parasitism by $E$. polistis still represents a strong selective pressure on $P$. versicolor. In future investigations, we intend to examine differences in wall thickness between nest cells of $P$. versicolor, and also the presence of closed cells surrounding the cells containing pupae and prepupae, which could be possible mechanisms to reduce the efficiency of parasitism.

\section{ACKNOWLEDGMENTS}

We would like to thank Valmir Antonio Costa for the confirmation of parasitoid wasp species and João Vasconcellos Neto for the critical reading of this manuscript. We were financially supported by Instituto Nacional de Ciência e Tecnologia dos Hymenoptera Parasitoides da Região Sudeste Brasileira (HYMPAR/Sudeste CNPq/FAPESP/CAPES), Conselho Nacional de Desenvolvimento Cientifico e tecnológico (CNPq - research grants to Sobczak J.F.), Coordenação de Aperfeiçoamento de Pessoal de Nível Superior (Capes - research grants to Messas Y.F., Souza H.S., Alvarenga T.M.). We also thanks the staff of Base de Estudos de Ecologia e Educação Ambiental da Serra do Japi.

Figure 1. Adult female of Elasmus polistis collected on prepupae of Polistes versicolor. 

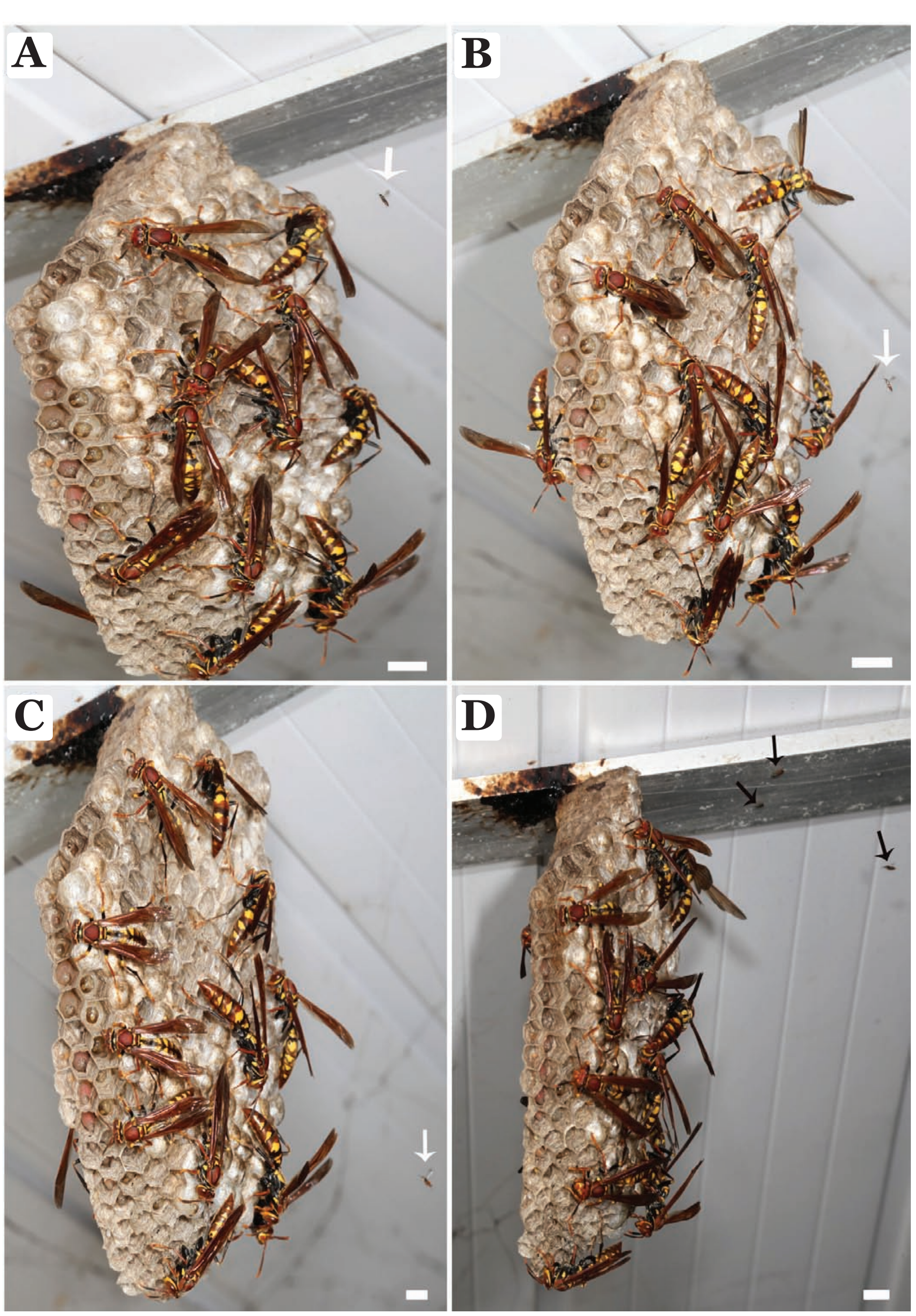

Figure 2. A - Elasmus polistis flying in front of and at the upper portion of the Polistes versicolor nest, seconds before the attack; B - flying in front and at the middle position; C - flying at the bottom of the nest; D - after the attack, Elasmus polistis lands near the nest of the host wasp. Scale bars $=1 \mathrm{~mm}$. 


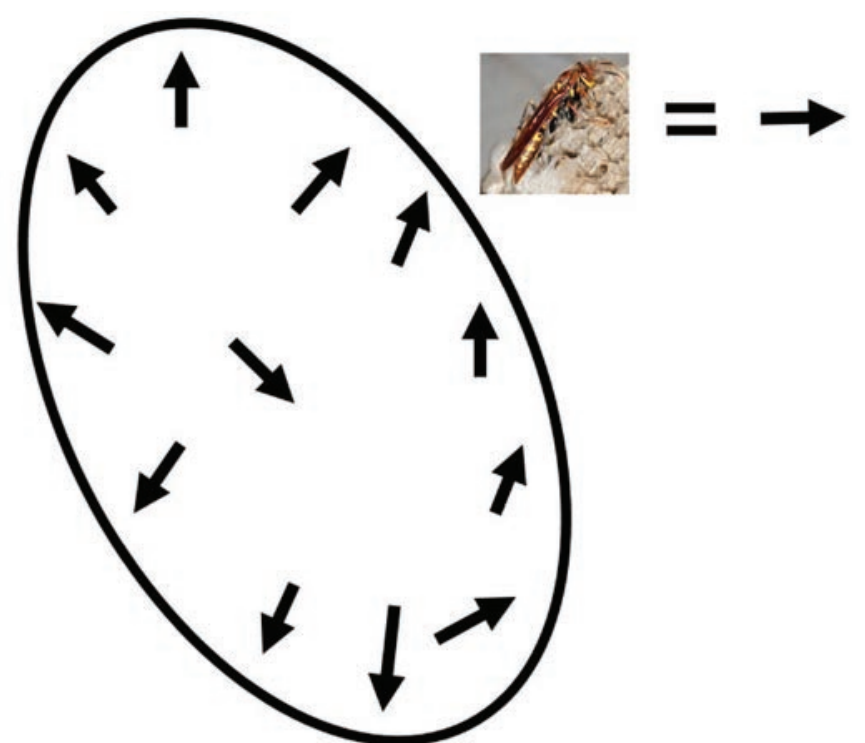

Figure 3. Schematic drawing of the Polistes versicolor nest with wasps patrolling the cells. The arrows represent $P$. versicolor individuals facing the edge of the nest.

\section{REFERENCES}

Coote, L.D., 1997. Elasmidae, p. 165-169. In: Gibson, Gibson, G.A.P.; Huber, J.T. \& Wooley, J.B. (Eds.). Annotated keys to the genera of Nearctic Chalcidoidea (Hymenoptera). NRC Research Press, Ottawa, 794 p.

Dietl, G.P. \& P.H. Kelley, 2002. The fossil record of predatorprey arms races: coevolution and escalation hypotheses, p. 353-374. In: Kowalewski, M. \& P. Kelley (Eds.). The Fossil record of prredation (vol 8). Paleontological Society Special Publication, New York, 398 p.

Dorfey, C. \& A. Kohler, 2011. First report of Elasmus polistes Burks (Hymenoptera: Eulophidae) recovered from Polistes versicolor (Oliver) (Hymenoptera: Vespidae) nests in Brazil. Neotropical Entomology, 40: 515-516.

Dury, G.J., J.C. Bede \& D.M. Windsor, 2014. Preemptive circular defence of immature insects: definition and occurrences of cycloalexy revisited. Psyche, 2014: 642908. doi:10.1155/2014/642908.

Futuyma, D.J. \& M. Slatkin, 1983. Introduction, p. 1-13. In: Futuyma, D.J. \& M. Slatkin (Eds.). Coevolution. Sinauer Associates, Sunderland, 555 p.

Gibson, G.A.P., 1993. Family Elasmidae, p. 626. In: Goulet, H. \& J.T. Huber (Eds.). Hymenoptera of the world: an identification guide to families. Research Branch Agriculture Canada Publication 1894/E, Ottawa, 668 p.

Hanson, P.E. \& I. D. Gauld. 2006. La Biología de los himenópteros, p. 11-16. In: Hanson, P. E. \& I. D. Gauld (Eds.). Hymenoptera de la Región Neotropical. Memories of the American Entomological Institute, Madison, 994 p.

Jolivet, P., J. Vasconcellos-Neto \& P. Weinstein, 1990. Cicloalexy: a new concept in the larval defense of insects. Insecta Mundi, 4: 133-142.
Lutz, G.G., J.E. Strassmann \& C.R. Hughes, 1984. Nest defense by the social wasps, Polistes exclamans and $P$. instabilis (Hymenoptera: Vespidae) against the parasitoid Elasmus polistis (Hymenoptera: Chalcidoidea: Eulophidae). Entomological News, 95: 47-50.

Macom, T.E. \& P.J. Landolt, 1995. Elasmus polistis (Hymenoptera: Eulophidae) recovered from nests of Polistes dorsalis (Hymenoptera: Vespidae) in Florida. The Florida Entomologist, 78:612-614.

Nelson, J.M., 1976. Elasmus polistis Burks (Hymenoptera: Eulophidae) reported in Oklahoma. Proceedings of the Oklahoma Academy of Science, 56:55.

Noyes, J.S., 2014. Universal Chalcidoidea Database - World Wide Web electronic publication. Available in: $<$ http://www. nhm.ac.uk/chalcidoids $>$. [Acessed: 09.09.2014].

Reed, H.C. \& S.B. Vinson, 1979. Observations of the life history and behavior of Elasmus polistis Burks (Hymenoptera: Chalcidoidea: Eulophidae). Journal of Kansas Entomological Society, 52: 247-257.

Santos, L.L.G., Y.F. Messas, H.S. Souza, T.M. Alvarenga \& J.F. Sobczak, 2013. Attack behavior of Elasmus versicolor (Hymenoptera: Eulophidae) in nest of Polistes versicolor (Hymenoptera: Vespidae) Movie Archives of Animal Behavior Data No. momo130414evo1b. Available in: <http://www. momo-p.com/index.php?movieid $=$ momo130414evo1b\&emb ed=on $>$. [Acessed in: 09.09.2014].

Thompson, J.N., 2001. Coevolution. In: Encyclopedia of Life Sciences. Nature Publishing Group, London. doi: 10.1038/ npg.els.0001761.

\section{Received in: 09/19/2014 \\ Accepted in: 03/11/2015}

\section{Suggested citation:}

Alvarenga, T.M., Y.F. Messas, H. da S. Souza, L.L.G. Santos, J.F. Sobczak, 2015. Attack Behavior of Elasmus polistis Burks (Hymenoptera: Eulophidae) in Nest of Polistes versicolor (Oliver) (Hymenoptera: Vespidae) and its Defensive Behavior. EntomoBrasilis, 8 (2): 155 -158.

Available in: $\underline{\text { doi:10.12741/ebrasilis.v8i2.475 }}$
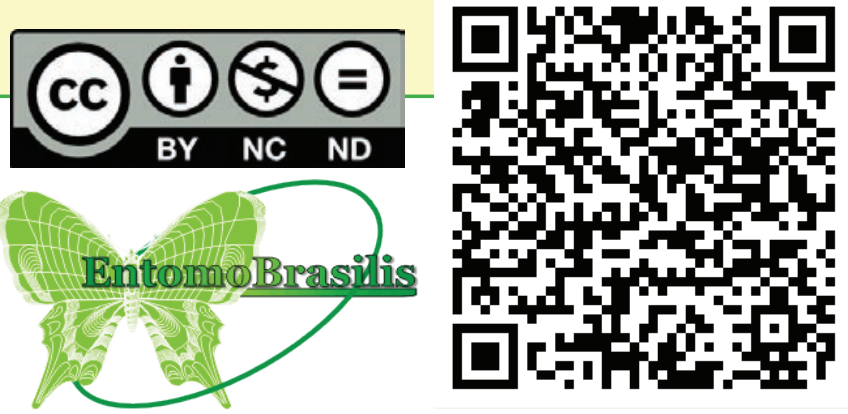